\section{France sets high targets for impact factors and patents}

[PARIS] Claude Allègre, France's minister of national education, research and technology, last week set the target of doubling the impact of French publications in the international scientific literature within four years. $\mathrm{He}$ also wants to triple the number of international patents held by French scientists, and to create several hundred stable hightechnology companies.

Allègre set these benchmarks following an interministerial meeting on research, chaired by Lionel Jospin, the prime minister. Allègre reiterated the strategy of his ministry, which is to support investigator-driven fundamental research, while exerting control over research with socioeconomic goals .

A National Science Council will be created to advise the government on research strategy. It will be composed of 20 or so eminent scientists and chaired by Allègre. Further advice will be solicited from the Academy of Sciences and other committees (see Nature 394, 9; 1998).

Allègre restated that the emphasis of evaluation procedures should shift away from evaluations of laboratories by commissions towards a system based on competitive proposals from individual research groups. More foreign researchers will be involved in conducting evaluations.

To help direct research towards wealth creation, Allègre confirmed the creation of a National Network of Technological Research, which will regroup laboratories working in key economic sectors.

Allègre rejected creating a full-blown postdoctoral system for French fundamental research scientists, and defended France's life tenure system. He said the bigger question was whether scientists should be full-time researchers for the whole of their careers or switch in later years to teaching, for example.

Some scientists say they hoped to see more concrete measures, but a ministry official refutes this criticism, arguing that the government has opened various avenues and that implementing change takes time.

Henri-Edouard Audier, a member of the board of the national union of scientific researchers, gives Allègre the benefit of the doubt, as the ministry now seems more willing to consult interested parties.

But many doubt the government's ability to meet its targets. French research publications have an impact score of 0.9 , according to the Paris-based Observatoire des Sciences et des Techniques. Doubling this means overtaking the United States (1.4) and Switzerland (1.5) at the top of the world league. Allègre's claims are "totally unrealistic", says one specialist in scientificindicators. DeclanButler

\title{
Congress revives hopes for solar power satellites
}

[WASHINGTON] A congressional committee has recommended a $\$ 20$ million increase to the US space agency NASA's budget to study a controversial idea that was all but laid to rest in the 1980s — solar power satellites (SPS) for beaming energy to Earth.

The increase is being urged by members of the House of Representatives, including space subcommittee chairman Dana Rohrabacher (Republican, California), who either have a long-standing interest in solar power satellites or who represent NASA centres that would conduct some of the research.

The idea of collecting solar energy with large satellites in space and transmitting it to the ground via microwaves was first proposed in 1968. Some $\$ 50$ million was spent on research at the Department of Energy and NASA in the late 1970s, but the concept was eventually shelved as being too expensive and requiring too many leaps in technology.

Last year, however, a small NASA team completed a two-year study of solar power satellites and found that enough had changed to warrant a revived research programme. Solar cell technology has improved, satellites are smaller and lighter, and SPS concepts no longer need hundreds of astronauts building gigantic structures in space.

NASA had planned to increase spending on SPS-related research from \$2 million to
\$5 million next year. But the Marshall Space Flight Center in Alabama is now working on an implementation plan for SPS research should the House and Senate approve the $\$ 20$ million increase later this year.

The House appropriations committee has called for NASA's Marshall and Lewis centres and its Jet Propulsion Laboratory to work with the energy department and private industry on SPS research. NASA is also funding Resources for the Future, a Washington think-tank, to conduct an economic analysis of the concept.

Proponents of SPS are more cautious in selling the idea than in the 1970s, when the satellites "only came in one size, and that was big," according to Whitt Brantley of Marshall's Advanced Systems and Technology Office. Short-term research is likely to focus on modest experiments to advance the basic technology, such as point-to-point transmission of large amounts of microwave energy on the ground or in low orbit.

But SPS must overcome the stigma resulting from the unrealistic plans of 20 years ago. Christopher Flavin of the Worldwatch Institute, which has been studying the terrestrial solar power industry, calls SPS "a real throwback," and criticizes Congress for starving conventional solar power research while pushing SPS.

TonyReichhardt

\section{Accelerator project digs itself into a hole}

[MOscow] The head of a leading Russian physics institute is under attack from colleagues for refusing to salvage a multimillion-dollar boring machine being used to dig a tunnel for a new particle accelerator.

Anatoly Logunov, director of the Russian Academy of Sciences' Institute of High Energy Physics in Protvino, 70 kilometres south of Moscow, is known for rejecting Einstein's theory of General Relativity, the existence of black holes and the 'Big Bang' for his own theories of matter.

He has decided to abandon a tunnelboring machine built by the Canadian company Lovat, said to have cost almost US\$18 million, following its completion of a tunnel required for the proton acceleratoraccumulator (PAA).

The machine, which is $\mathbf{5 5}$ metres long and weighs 360 tonnes, can cover 100 metres in 24 hours, and has almost completed its task. "It would cost only 2.5 million roubles $(\$ 400,000)$ to bring the machine to the surface," says Vasily Pasika, the engineer-inchief of the PAA tunnel-building company.

The PAA project received priority treatment from the government, but has run into financial problems. It was allocated 56 million roubles in the 1998 budget, but in April this was cut to 39 million roubles, and by June the institute had received only 6 million roubles.

Logunov says the institute has no market for the project's only product — mu mesons — and no other income. "Many of our scientists have gone abroad, and with salaries here at less than $\$ 100$ a month, I can't blame them," he says. He says the tunnelling machine is the best in the world, "but we have no money to maintain it".

Water enters the tunnel at a daily rate of 30-40 cubic metres, but the pumps are switched off because there is no money for electricity. Technicians, who have long been unpaid, occasionally struggle through the tunnel to check that the borer is working.

There are many potential purchasers for the machine, once it has been brought above ground. It is wanted for the Moscow subway, and four Russian cities - Chelyabinsk, Ufa, Kazan and Krasnoyarsk - have each offered $\$ 18$ million for it.

Carl Levitin 